\title{
BANSKOBYSTRICKÁ KAPITULA AKO HODNOVERNÉ MIESTO VO SVETLE DOCHOVANÝCH PRAMEŇOV V ROKOCH $1780-1790$
}

\author{
Banská Bystrica Chapter as the Place of Authentication \\ in the Light of Preserved Sources in 1780 - 1790
}

\author{
Zuzana Mičková - Peter Mičko
}

DOI: 10.17846/CL.2021.14.2.126-138

\begin{abstract}
MIČKOVÁ, Zuzana - MIČKO, Peter. Banská Bystrica Chapter as the Place of Authentication in the Light of Preserved Sources in 1780 - 1790. The research subject of the presented study is the activity of the Banská Bystrica Chapter as the place of authentication (locus credibilis) in the first decade of its existence. The authors focus on the establishment conditions of the Chapter as part of the Diocese of Banská Bystrica in 1776 and the subsequent relocation of the Turiec convent place of authentication archives from Kláštor pod Znievom to Banská Bystrica in 1780. Moreover, the authors attempt to reconstruct the activities of a place of authentication, to present the personnel and economic background of the Chapter according to authentic descriptions drawing on the canonical visitations of 1785 . Subsequently, they aim to demonstrate the structure and the amount of agenda of the place of authentication in the first decade of its existence according to the hitherto unresearched protocol of the credible place from 1780 - 1795 stored in the archives of the Diocese of Banská Bystrica. Finally, the authors follow the efforts of Emperor Joseph II to gradually centralize the places of authentication archives which, however, were not implemented due to the reasons stated in the study.
\end{abstract}

Keywords: chapter, Banská Bystrica, locus credibilis, place of authentication, Joseph II.

\section{Úvod}

Hodnoverné miesta (loca credibilia) ako inštitúcie verejného notárstva sú špecifikom uhorských dejín a ich význam je zo všetkých aspektov historického výskumu, či už ide o cirkevné dejiny, právne dejiny, pomocné vedy historické, či regionálne dejiny, nedocenitelný. Vrcholom pôsobenia hodnoverných miest je obdobie konca stredoveku a počiatku novoveku. V neskoršom období si svoj status v oblasti notárstva síce udržali, no ich význam postupne klesal. Najstarším hodnoverným miestam pôsobiacim na území dnešného Slovenska sa už slovenská historiografia vo väčšej miere venovala. Čo sa týka Banskobystrickej kapituly ako hodnoverného miesta, tu je situácia odlišná. Banskobystrická kapitula ako hodnoverné miesto začala svoju činnost̉ v roku $1780 \mathrm{v}$ pozícii priameho pokračovatela hodnoverného miesta - Turčianskeho konventu, ktoré bolo premonštrátmi založené už v roku 1251, pričom prvý známy odtlačok stredovekej pečate tejto inštitúcie pochádza z roku 1291 (Takács 1992, 90). Banskobystrické obdobie daného hodnoverného miesta tak patrí do záverečnej éry fungovania a vplyvu inštitúcií hodnoverných miest. Z aspektu cirkevnej histórie sa z radov teológov venovalo niekol'ko prác Banskobystrickej kapitule (Juhaniak 2016; 
Brendza 2003), no Banskobystrická kapitula a jej činnost’ hodnoverného miesta je dosial'v podstate nespracovanou témou. Kým archív hodnoverného miesta v Turci je sústredený v Slovenskom národnom archíve v Bratislave s označením fondu Hodnoverné miesto Konventu premonštrátov v Turci, s časovým rozsahom (1259) 1288 - 1912, jeho čast’ práve z obdobia pôsobenia hodnoverného miesta v Banskej Bystrici sa nachádza v Diecéznom archíve Banskobystrického biskupstva dosial' v nespracovanom a nezdokumentovanom stave. Predmetom tejto štúdie je poukázat' na klúčové body, ako sú založenie diecézy a kapituly v Banskej Bystrici, celospoločenské faktory, ktoré k takémuto vývoju prispeli, dôvody a spôsob prestahovania archívu hodnoverného miesta a náčrt fungovania inštitúcie v prvom desatročí svojho pôsobenia v Banskej Bystrici.

\section{Založenie Banskobystrickej diecézy a prepošstva v Banskej Bystrici}

Zámer vytvorit’ v rámci ostrihomskej arcidiecézy menšie cirkevné správne jednotky - diecézy možno sledovat' už od vlády Ludovíta I. Vel'kého (Tomko 1995). K reálnemu aktu dismembrácie ostrihomskej arcidiecézy však konečne došlo ovela neskôr, konkrétne dňa 13. marca v roku 1776, ked’ Pápež Pius VI. vyhovel žiadosti resp. návrhu Márie Terézie a v pápežskej bule Regalium principum vyslovil súhlas, že na území Ostrihomskej arcidiecézy vzniknú tri nové diecézy, a to v Banskej Bystrici, Rožňave a Spišskej Kapitule. ${ }^{1}$ Dôvody, prečo k tomuto aktu napriek vel'kej rozlohe a hustote obyvatel'stva arcidiecézy neprišlo skôr, možno hladat najmä v nestabilnej politickej a náboženskej situácii v Uhorsku počas predchádzajúcich storočí. Podmienky na uskutočnenie aktu dismembrácie Ostrihomskej arcidiecézy tak definitívne dozreli v poslednej štvrtine 18. storočia. Výrazné urýchlovače procesu vytvorenia nových diecéz boli najmä dva. Zrušenie Spoločnosti Ježišovej na základe breve pápeža Klementa XIV. zo dňa 21. júla 1773, ku ktorému v habsburskej monarchii došlo v októbri toho istého roka (Krapka - Mikula 1990, 276, 282) a zároveň absolutistické chápanie moci panovníka, zahŕňajúcej i oblast̉ cirkevnej politiky. Zásahy štátnej moci do cirkevných záležitostí so snahou o ich reformovanie v duchu jozefinizmu² sú tak typickou črtou tohto obdobia.

Odrazom uvedeného je aj nami spracovaná otázka fungovania Banskobystrickej kapituly ako hodnoverného miesta v rokoch 1780 - 1790.

Zároveň s Banskobystrickou diecézou bolo spomínanou bulou zriadené taktiež prepošstvo, ktorého súčastou bola sídelná kapitula - zbor kanonikov pri katedrálnom kostole. Kapitula sa skladala zo šiestich členov: velprepošta, lektora, kantora, kustóda a dvoch kanonikov bez hodnosti (Koniarová 2002, 41-42). Možno konštatovat', že išlo o štandardnú štruktúru kapituly

1 Úryvok z pápežskej buly Regaliumprincipum $\$ 3$, „My, po zvážení všetkých záležitostí v pravom čase, po vypočutí rady [...] chceme vyhoviet' Márii Terézii [...]. Z vlastnej pohnútky (motu proprio) a zo zisteného poznania uvedené mesto Banskú Bystricu apoštolskou mocou úplne a naveky odčleňujeme od Ostrihomskej arcidiecézy, a samotné mesto Banskú Bystricu uvedenou apoštolskou mocou podla kánonických predpisov natrvalo povyšujeme titulom a poctou biskupského mesta. Náš milovaný syn, viedenský nuncius Apoštolskej stolice, má určit, ktorý kostol v tomto meste, v Banskej Bystrici [...] sa stane katedrálnym kostolom [...]. A $v$ tomto kostole má byt zriadené jedno prepošstvo, kde bude okrem velprepošta aj jeden lektor, to bude druhá hodnost', bude tam jeden kantor, to bude tretia hodnost’ a bude tam jeden strážca, čiže budú tam štyria hodnostári. Taktiež rôzne kanonikáty a prebedy pre všetkých klerikov, či budúcich kňazov, aj pre lektora, kantora, kustóda a pre jedného i druhého kanonika, a tak ako sa ukazuje, treba zvolit kapitulu spomínaného kostola, ktorý bude povýšený na katedrálny. Kapitula spomínaného kostola sa má skladat zo šiestich členov [...]“" (Koniarová 2002, 41-42).

2 K otázke jozefinizmu pozri bližšie: Winter 1948. 
z konca 18. storočia. ${ }^{3}$ Kanonikov menovala sama panovníčka. ${ }^{4}$ Pôvodne bolo menovanie kanonikov v Uhorsku v kompetencii biskupov, no na základe breve, v ktoromPápež Klement XIII. udelil Márii Terézii a jej potomkom titul „Rex Apostolicus" si uvedené právo v kombinácii s patronátnym právom uhorských králov a myšlienkami jozefinizmu prisvojila panovníčka (Tomko 1995, 33-34). Právo mala panovníčka $\mathrm{v}$ konečnom dôsledku potvrdené i pápežom v spomínanej bule Regalium principum. ${ }^{5}$

Na zabezpečenie ludských a ekonomických zdrojov novovzniknutej Kapituly boli využité v oboch sférach kapacity, ktoré sa uvolnili po zrušení Spoločnosti Ježišovej.

Do konca roka boli kanonikáty obsadené najmä bývalými jezuitmi a základným hospodárskym zázemím biskupstva a kapituly sa zase stali niekdajšie jezuitské majetky.

Banskobystrická kapitula nemala spočiatku vlastné štatúty, a tak sa riadila štatútmi používanými kapitulou v Bratislave ${ }^{6}$ (tento stav trval do toku 1785). Inštaláciou nových kanonikov bol poverený kanonik Bratislavskej kapituly, Martin Gőrgei, ktorý ich v novovymenovanej Katedrále sv. Františka Xaverského v Banskej Bystrici uviedol do úradu 27. októbra 1776 (Schematismus 1876, 48; Juhaniak 2016, 32). Prvé konzistórium sa konalo 19. decembra 1776 (Schematismus 1876, 11; Koniarová 2002, 56).

Prvým velprepoštom Banskobystrickej kapituly bol panovníčkou menovaný bývalý viedenský univerzitný profesor a rakúsky provinciál zrušenej Spoločnosti Ježišovej v Rakúsku, Mikuláš Muszka (62 r.). Hodnost’ velprepošta zastával do svojej smrti 11. septembra 1783 (Schematismus 1876, 55-56).

Prvým lektorom Kapituly sa stal Martin Matejovicz (42 r.). Pred menovaním za kanonika pôsobil ako farár v Sobotišti a vicearchidiakon senického dištriktu. Po smrti Mikuláša Muszku bol menovaný za velprepošta (DABB, f. KVBD, 1754 - 1830, CV19C II., 27).

Kantorom bol menovaný Jozef Juraczska (51 r.), pôvodne zvolenský farár a vicearchidiakon dolného zvolenského dištriktu (DABB, f. KVBD, 1754 - 1830, CV19C II., 27).

Kustódom sa stal Karol Pallits (42 r.), ktorý na rozdiel od ostatných kanonikov nepochádzal z územia severného Uhorska, ale z Banátu. Pred menovaním za kanonika bola jeho posledným pôsobiskom farnost' Slovenská Lupča, pričom zároveň zastával post vicearchidiakona horného zvolenského dištriktu. Od roku 1794, po smrti spolukanonika Jozefa Juracsku, sa stal kantorom kapituly (DABB, f. KVBD, 1754 - 1830, CV19C II., 27).

Kanonici bez hodnosti - jednoduchí kanonici, boli dvaja. Prvý bol menovaný do pozície kanonika seniora Jozef Janovszky (46 r.) a druhý do pozície kanonika juniora Mathias Plathy (51 r.). Obaja boli bývalí jezuiti, svojho času prednášajúci na Trnavskej univerzite.

Jozef Janovzsky v kapitule zastával zároveň post dekana (DABB, f. KVBD, 1754 - 1830, CV19C II., 28).

Mathias Plathy z Paludze ${ }^{7}$ sa pred svojím pôsobením v kapitule venoval najmä pedagogickej činnosti. Neskôr spravoval záležitosti spoločnosti Ježišovej v Budíne a bezprostredne po jej zrušení sa uplatnil pri královskej kúrii, konkrétne u královského prokurátora. Znalosti práva využil

3 Obdobnú štruktúru kapituly možno sledovat v Rožňave a neskôr i v Košiciach (Zubko 2003, 9).

4 K otázke patronátneho práva pozri bližšie: Tomko 1995.

5 Úryvok z pápežskej buly Regaliumprincipum $\$ 5$ „Okrem toho takým istým spôsobom Márii Terézii, apoštolskej královnej, aj jej královským nástupcom v spominanom královstve apoštolskou mocou naveky udelujeme a ponechávame právo udelovat všetky cirkevné benefíciá, kanonikáty a prebendy v kapitule spominaného, nami povýšeného banskobystrického katedrálneho kostola..."(Koniarová, 2002, 46).

6 Táto skutočnoste vysvetluje dôvod, prečo sa v banskobystrickom diecéznom archíve nachádzajú štatúty Bratislavskej kapituly. Tieto štatúty sú síce bez datovania, no z ich obsahu vyplýva, že ide o štatúty novoveké (DABB, f. K-BB, k. P115).

7 Dnes zaniknutá obec Palúdzka je súčastou Liptovského Mikuláša. 
aj v Banskej Bystrici, ked' kapitulu zastupoval v právnych sporoch. Po smrti prvého velprepošta sa stal lektorom kapituly. Popri kanonikáte bol zároveň riaditelom banskobystrického biskupského gymnázia (pokračovatela jezuitského kolégia) a turčianskym archidiakonom (DABB, f. KVBD, 1754 - 1830, CV19C II., 27).

$\mathrm{V}$ roku 1784 počet kanonikov po smrti velprepošta doplnil opät bývalý jezuita Anton Okolicsány, ktorý pôsobil do menovania za kanonika ako farár v Detve (DABB, f. KVBD, 1754 1830, CV19C II.).

Sídlom kapituly sa stalo bývalé jezuitské kolégium. Velprepošt obýval dom na hlavnom námestí vedla Katedrály sv. Františka Xaverského v tzv. Oberhause a ostatní kanonici obývali samostatné byty v budove bývalého jezuitského kolégia (Schematismus 1876, 48).

Hospodárske zázemie kapituly sa nachádzalo najmä v Hontianskej stolici v okolí Bátoviec-Pečenice a Dolné Jabloňovce, v Hokovciach, v Hontianskych Trstanoch, dalej išlo o usadlost' Korbasz, situovanú medzi obcami Hokovce a Opátove Moravce ${ }^{8}$ a usadlost' Hereczeg, ležiacu medzi Domadicami a Bormi. Okrem spomenutého mala kapitula v správe i majetky v Liptovskej Sielnici, príjmy opátstva vo Svätej Mare v Liptove a neskôr bola kapitule pridelená obec Zvolenská Sielnica. V rámci týchto majetkov kapitula disponovala polami, lúkami, lesmi, vinicami, rožným statkom, ovčími stádami. V menovaných majetkoch sa nachádzali mlyny, stodoly, bitúnky, pivovar, pálenice, kováčske dielne, pivnice. Na konci parcely svojej banskobystrickej rezidencie, siahajúcej od námestia po Hron, mala kapitula záhrady (DABB, f. KVBD, 1754 - 1830, CV19C II., 33-35).

Kapitula sa tak ako jej predchodcovia, jezuiti, zaoberala aj predajom vína na banskobystrickom námestí, pričom sa odvolávala na staré právo predaja vína, či piva viazaného k cirkulárnych domom (Jurkovič 2005, 202). ${ }^{9}$

Dozor nad celým hospodárením kapituly mal kanonik, dekan, ktorému sa zodpovedali správcovia jednotlivých hospodárskych majetkov, dohliadajúci zároveň na plnenie povinnosti urbariálnych poddaných.

Kapitule prináležal d’alej desiatok z bojnického panstva, ktorý bol však prenajatý Jánovi Pálffymu za 1632 zlatých. Kapitula spravovala mnohé fundácie a od roku 1780 mala aj príjmy z činnosti hodnoverného miesta (DABB, f. KVBD, 1754 - 1830, CV19C II., 36).

Súčastou personálneho zázemia kapituly boli okrem už spomenutých urbariálnych poddaných a správcov majetkov svetské osoby ako sluhovia, či zvonár. V katedrálnom kostole, ktorý patril pôvodne jezuitom, pôsobili okrem kanonikov ešte další štyria kňazi (DABB, f. KVBD, 1754 - 1830, CV19C I., 26-27)..$^{10}$

Po oficiálnom zrušení Spoločnosti Ježišovej sa tak v Banskej Bystrici nadalej v pretransformovanej forme stretávame s jej bývalými členmi i majetkom.

Vyššie spomenuté potvrdzujú i zápisy z banskobystrickej katolíckej matriky zosnulých, v ktorej možno sledovat, že okrem spomenutých kanonikov sa v Banskej Bystrici stretávame ešte s niekolkými členmi zrušenej Spoločnosti Ježišovej, ktorí tu dožili. Ako príklad možno spomenút bývalého rektora jezuitského kolégia, neskoršieho administrátora banskobystrickej farnosti Michaela Scheftsika, dalej profesora gymnázia Ignáca Gyürtsaka, či neskoršieho banskobystrického farára Ignáca Raucha (ŠA BB f. ZM, MD 1780 - 1841, RC - FBB).

Z uvedeného je teda evidentné, že bývalí jezuiti sa v novovytvorenom biskupstve hojne uplatnili. Takéto riešenie nebolo špecifické len pre Banskú Bystricu, viacerí poprední jezuiti dostali

V súčasnosti je to súčast' obce Hontianske Moravce.

9 O oprávnenost’ predaja vína sa mesto súdilo i s jezuitmi a po vzniku biskupstva aj s kapitulou (Jurkovič 2005, 202).

10 DABB, fond Kánonické vizitácie Banskobystrickej diecézy 1754 - 1830, CV19C I. 26-27. 
po zrušení rehole významné cirkevné pozície a rádoví členovia svoje farnosti (Krapka - Mikula 1990, 307).

\section{Stahovanie archívu hodnoverného mieste, začiatok činnosti hodnoverné- ho miesta v Banskej Bystrici}

Banskobystrická kapitula prebrala okrem svojich cirkevných povinností, ktoré nie sú predmetom tejto štúdie, aj povinnosti svetského charakteru. Od roku 1780 začala vykonávat činnost' hodnoverného miesta ako priameho nástupcu hodnoverného miesta Turčianskeho konventu Panny Márie v Kláštore pod Znievom.

Administratívnym podkladom zmeny bolo rozhodnutie Miestodržitelskej rady, odsúhlasené Máriou Teréziou, o prestahovaní archívu hodnoverného miesta z Kláštora pod Znievom do Banskej Bystrice, ktoré bolo vydané 10. júla 1780. O tomto kroku boli písomne upovedomené všetky dotknuté strany. Podla odpisu dokumentu v protokole hodnoverného miesta (DABB, f. K-BB, k. P113) ${ }^{11}$ vieme o priebehu realizovaného aktu nasledovné:

$\mathrm{V}$ bode a) bol určený termín prestahovania archívu hodnoverného miesta, ktorý bol podla zistení Miestodržitel'skej rady „desolato in statu“. Stahovanie malo prebehnút po 1. auguste toho istého roku.

V bode b)Miestodržitel'ská rada nariadila, že až do konania zasadania snemu majú byt dokumenty nadalej vydávané pod pečatou Turčianskeho konventu Panny Márie. (Tento stav sa nakoniec nezmenil pri najbližšom zasadaní snemu, ktorý bol zvolaný Leopoldom II. v roku 1790, ale až v roku 1802, ked’ bola Františkom II. po schválení snemu, teda po prebehnutí legislatívneho procesu, udelená Banskobystrickej kapitule konečne vlastná pečat'). ${ }^{12}$

V bode c) sa nariadovalo, aby bol prestahovaný archív uložený na mieste bezpečnom, suchom a spolahlivo chránenom $\mathrm{v}$ prípade požiaru.

V bode d) bolo presne popísané, ako sa má preberanie archívu zrealizovat. Za Banskobystrickú kapitulu mali byt v dohodnutom čase a na určenom mieste, kde bol uchovávaný archív vyslaní velprepošt a lektor, ktorí ešte predtým zložili prísahu konventu. Na mieste, za účasti súčasných príslušníkov konventu, turčianskych stoličných úradníkov a notára turčianskeho konventu prebrali od znievskeho farára, zároveň správcu hodnoverného miesta, podla predloženého súhrnu všetky prezreté spisy. Následne mali byt všetky spisy v sprievode turčianskych stoličných úradníkov opatrené pečatou a rýchlo prevezené do Banskej Bystrice. V Banskej Bystrici za prítomnosti celej kapituly, stoličných úradníkov turčianskych, ako aj zvolenských mali byt spisy odpečatené, znovu prezreté a uložené na určené miesto. Od 1. augusta tak kapitula mohla začat podla zaslaného rozhodnutia vystavovat dokumenty.

11 Ide o prvý protokol vedený Banskobystrickou kapitulou a rozhodnutie Miestodržitel’skej rady je prvým zaprotokolovaným dokumentom. Protocollum Loci Credibilis 1780 - 1795 je uložený v Diecéznom archíve v Banskej Bystrici, vo fonde Kapitula - Banská Bystrica v kartóne označenom ako P113.

12 Na sneme v roku 1802, zákonom č. 15 bolo rozhodnuté poverit Banskobystrickú kapitulu samostatným vedením hodnoverného miesta s vlastnou pečatou, ktorú jej mal podla $\$ 1$ určit panovník. Za právoplatné boli dodatočne uznané všetky verejné listiny, ktoré kapitula vydala v mene Turčianskeho konventu od roku 1780 (Mišík 1963, 80). Podoba pečate je nasledovná: V hlavnom poli je vyobrazená Panna Mária sediaca na tróne s korunou na hlave a s Jezuliatkom stojacim na jej lavom stehne. Po stranách stredového pola pečate sa nachádzajú taktiež ako na pečati turčianskeho konventu na lavej strane písmená I.H.V. (IN HONOREM VIRGINIS), pod ktorými je hviezda a na pravej strane písmená MR.DNI (MATRIS DOMINI), pod ktorými je rastúca luna. Na okraji pečatného pola sa nachádza majuskulná legenda SIGILLUM CAPITULI NEOSOLIENSIS ANNO 1802 (Juhaniak 2016, 38, XVI). 
Zároveň s predchádzajúcimi bodmi bolo hodnovernému miestu ako hospodárske zázemie udelená obec Zvolenská Sielnica, ktorá predtým patrila turčianskemu prepošstvu - prepozitúre, neskôr bola súčastou fondu na financovanie univerzity v Budíne a pred 10. júlom 1780 bola súčastou všeobecného študentského fondu(ad generalem fundi studiorum pretinentem).

Rozhodnutie Miestodržitel’skej rady bolo plne akceptované. Svedčia o tom nasledujúce odpisy v protokole. Dňa 28. júla 1780, zložili konventuálnu prísahu predznievskym farárom Ignácom Czeppánom a zároveň predstaveným konventu, ostatnými členmi konventu a zástupcami Turčianskej stolice vyslaní zástupcovia Banskobystrickej kapituly, velprepošt Mikuláš Muszka a lektor Martin Matejovicz.

Uskutočneným aktom predstavitelia Banskobystrickej kapituly prevzali na seba záväzok správy a starosti o pečat' hodnoverného miesta, protokoly a listiny a prisahali vernost' nadriadeným cirkevným hodnostárom.

Podla dokumentu, ktorý vznikol 3. augusta 1780, došlo následne k odovzdaniu pečate a archívu za prítomnosti už vyššie spomenutých svedkov. Bol vypracovaný zoznam archívnych protokolov a očíslovaných nezaprotokolovaných zväzkov. Celý tento zoznam sa stal súčastou odovzdania archívu.

Dňa 9. augusta bol archív hodnoverného miesta už definitívne v Banskej Bystrici. Na mieste zložili konventuálnu prísahu všetci ostatní banskobystrickí kanonici a další zúčastnení úradníci. Dňa 10. augusta zložil prísahu aj novovymenovaný notár hodnoverného miesta Karol Matyus.

Posledným aktom sa prenos archívu zavíšil a Banskobystrická kapitula pod hlavičkou Turčianskeho konventu Panny Márie a s pečatou tohto konventu začala činnost’ hodnoverného miesta (DABB, f. K-BB, k. P113).

Presídlenie konventu sa nestretlo so spokojnostou najmä v zainteresovaných stoliciach, pričom konkrétne dôvody nepoznáme. V roku 1782 podali urgenciu so žiadostou, aby snem rozhodol o návrate konventu do Kláštora pod Znievom. Snem sa ale do roku 1790 nezišiel, urgencia stratila za tento čas na aktuálnosti a do zániku hodnoverných miest v roku 1874 už zostalo pri status quo (Mišík 1963, 80).

\section{Vnútorná organizácia Banskobystrickej kapituly ako hodnoverného miesta v rokoch $1780-1790$}

O vnútornej organizácii a živote kapituly ako hodnoverného miestasa dozvedáme najmä vdaka kanonickým vizitáciám. V nami sledovanom období bola vykonaná vizitácia kapituly v roku 1785, prvým banskobystrickým biskupom grófom Františkom Berchtoldom. Čo sa týka činnosti hodnoverného miesta - konventu, najviac sa dozvedáme v kapitole 8.vizitačného protokolu De Actibus et Obligationibus Fide Dignitatis Legalis a v štatútoch kapituly, zaznamenaných v totožnom vizitačnom protokole (DABB, f. KVBD, 1754 - 1830, CV19C I.).

$\mathrm{Na}$ činnosti hodnoverného miesta sa $\mathrm{z}$ kanonického zboru podielali najmä velprepošt, lektor a kustód. No nie je výnimkou, že na listinách sú okrem lektora a kustóda ako zástupcovia kapituly uvádzaní všetci členovia konventu alebo len lektor a kanonik bez hodnosti (DABB, f. K-BB, k. P120). Nevyhnutnou súčastou vierohodného miesta bol aj notár.

Velprepošt kapituly dohliadal na činnost̉ celej kapituly a ako predstavený Konventu Panny Márie v Turci bolo v jeho kompetencii povolávat kanonikov konventu k vydávaniu dosvedčujúcich listín, štatutácií, testamentov, prokuračných listín, splnomocňujúcich listín a všetkých ostatných dokumentov týkajúcich sa verejných právnych záležitostí (DABB, f. KVBD, $1754-1830$, CV19C I., 65). 
Povinnostou lektora - kanonika v organizácii hodnoverného miesta - konventu bolo všetky návrhy vydávaných listín koncipovat a predčítat kapitule. Písomnosti musel následne doslovne zaznamenat do protokolu - knihy zaprotokolovaných dokumentov, či už išlo o panovnícke mandáty, úradné nariadenia Miestodržitel'skej rady, Královskej komory, rozhodnutia diecézneho biskupa, či všetky reskripty priamo smerované na kapitulu. Zostavoval taktiež odpovede kapituly v rámci úradnej korešpondencie. Jeho úlohou bolo zachovávat poriadok v archíve kapituly, pričom v tomto prípade išlo o archív kapituly - „archivum Capituli“, nie archív hodnoverného miesta. Nakoniec všetky dokumenty, už prečítané notárom musel opätovne, predložit', prečítat a následne podpísat' (DABB, f. KVBD, 1754 - 1830, CV19C I., 66).

Kustód - so zretelom na činnost' hodnoverného miesta, mal povinnost’ vydané a lektorom podpísané dokumenty, opatrit pečatou. Pri pečatení mal byt' prítomný lektor, členovia konventu, minimálne však notár. Uchovával taktiež klúče od archívu hodnoverného miesta - „archivum publicum“, ktoré nesmel zverit nikomu okrem členov konventu, i to len s vedomím prepošta a v prípade jeho neprítomnosti. Pod jeho dozorom bola aj autentická pečat hodnoverného miesta, ktorá bola zároveň s dokumentmi zamknutá $\mathrm{v}$ archíve. Úlohou kustóda bolo taktiež odpečatovat za prítomnosti členov konventu vyšetrovacie mandáty „mandata requisitoria“. Vyberal poplatky za vystavenie dokumentov hodnoverného miesta a na konci roka nazhromaždenú sumu rozdelil medzi ordinárov kapituly, podla zaužívaného pravidla (DABB, f. KVBD, 1754 - 1830, CV19C II., 30). Dôsledne sa mal starat' o protokoly, ktoré u seba nemohol uchovávat', ale ihned' po vydaní hladaných listín, ich musel vrátit do archívu. Klúče od sakristie, kde sa konali konzistóriá kapituly, nemohol za žiadnych okolností zverit svetskému človeku, ale $\mathrm{v}$ prípade choroby alebo $\mathrm{z}$ iného závažného dôvodu ich mal zverit niekomu z grémia s vedomím prepošta, a v jeho neprítomnosti lektora. V neposlednom rade boli v jeho kompetencii osoby, ktoré královská kúria postúpila na kapitulu, z dôvodu vykonania právneho aktu prísahy. Prísaha bola zložená po hlavnej omši prisahajúcimi osobami, ktoré ju obrátené smerom k oltáru a nad knihou Svätého písma, za prítomnosti niekolkých kanonikov predniesli zretelným hlasom (DABB, f. KVBD, 1754 - 1830, CV19C I., 67).

Svetský element hodnoverného miesta - notár bol na začiatku svojho pôsobenia povinný zložit presne formulovanú prísahu, ${ }^{13}$ ktorou sa zaviazal vydávat pravé a zákonné dokumenty v súlade so zákonmi krajiny. Okrem základnej povinnosti dodržiavania prísahy bolo jeho dalšou povinnostou uchovávat' protokoly konventu, $\mathrm{v}$ ktorých nemal právo pridat', odstránit’ alebo opravit’ ani „jotu“ alebo „dľžku“. Riadit sa mal nariadeniami konventu a bez vedomia velprepošta sa nesmel z blízkosti kapituly vzdialit na viac ako deň. Ku klientom - causantibus sa mal správat ludsky. Nemal zdržovat vybavovanie odkladmi. Nesmel žiadat vyššiu sumu, ako boli predpísané poplatky. Pevný plat notára konventu $\mathrm{v}$ tomto čase predstavoval 100 zlatých, k čomu malnárok na dalšie vyúčtovanie z vydaných listín (DABB, f. KVBD, 1754 - 1830, CV19C I., 38-39).

Prvým notárom konventu bol už spomínaný Karol Matyus. V roku 1785 bol zvolený nový notár pre hodnoverné miesto, Joannes Schurman (DABB, f. K-BB, k. P113, 216), vo vizitáciách opísaný ako znalý krajinského práva a pevnej viery „Iuris patrii gnarus et integrae fidei“. Post notára konventu zastával až do svojej rezignácie v roku 1794, ked’ sa jeho nástupcom stal Jozef Thuolth, ktorý podla zápisu v protokole vypomáhal konventu ako notár už pre rokom 1794 (DABB, f. K-BB, k. P113, 704).

13 Prísaha notára znela nasledovne: „Ego N.N. electus Notarius Conventus B. M.V de Thurócz juro per Deum Sanctum. Sanctam et individuam Trinitatem Beatissimam Mariam semper Virginem, et omnes Sanctos, quod ego omnibus, et singulis, coram me causantis de Lege Regni veras et legitimas litteras emanabo, Protocolla conventus fideliter conservabo, superioribus meis fidelis ero, sic me Deus adjuvet, B. V. Maria et omnes Sancti“ (DABB, f. KVBD, 1754 - 1830, CV19C I., 38). 
Vykonávanie aktu vierohodnosti od prijatia žiadosti po vydanie požadovaného dokumentu prípadne svedectva malo jasné pravidlá.

Žiadost’ na vydanie akéhokolvek dokumentu konventom musela byt najprv prečítaná za prítomnosti členov konventu. Požadovaný dokument lektor následne spísal a spolu s kustódom zaniesol notárovi konventu. Notár upravil dokument formálne a štylisticky. Takto pripravený dokument bol prinesený opät lektorovi, ktorý ho starostlivo skontroloval, eventuálne pri odpise porovnal s originálnym dokumentom. V prípade potrebnej opravy sa za žiadnych okolností nemohlo zasahovat do samotného textu. Na konci dokumentu (predtým, ako bol opatrený pečatou) vlastnou rukou pridal lektor formulku, v ktorej bola uvedená osoba upravujúca základné znenie dokumentu a navrhujúca správnu formuláciu konkrétneho riadku. Pripravený dokument lektor podpísal s vyjadrením „prečítané a vydané lektorom konventu N. N.“. Pečatenie dokumentu vykonával kustód za prítomnosti notára. Všetky verejnoprávne dokumenty boli uchovávané v archíve na suchom mieste pod dozorom kustóda.

Vyhlasujúce či dosvedčujúce listiny boli vystavené aj za prítomností tých, ktorí ich predkladali, a pred podpisom boliešte prečítané lektorom (DABB, f. KVBD, 1754 - 1830,CV19C II., 46).

Poplatky za jednotlivé typy dokumentov sa vyberali podla královského mandátu z 13. augusta 1770. Pokial' sa však spory a právne záležitosti týkali chudobných alebo biednych osôb, o ktorých to bolo bud' verejne známe, alebo dokázané dosvedčujúcimi listinami, vtedy mali byt písomnosti vyhotovené zadarmo, bez zbytočných prietahov (DABB, f. KVBD, 1754 - 1830, CV19C II., 47).

\section{Agenda hodnoverného miesta v rokoch 1780 - 1790}

Od roku 1780, konkrétne od dátumu, ked’ Miestodržitel’ská rada nariadila prestahovanie archívu hodnoverného miesta do Banskej Bystrice, bola agenda hodnoverného miesta zaprotokolovaná v protokole Konventu Panny Márie z Turca Banskobystrickou kapitulou. Tento protokol sa v súčasnosti nachádza v Diecéznom archíve banskobystrického biskupstva (DABB, f. K-BB, k. P113). Vd’aka jeho existencii si tak možno spravit presnú predstavu o množstve a typológii jednotlivých právnych aktov, ${ }^{14}$ vykonaných hodnoverným miestom v sledovanom období.

$\mathrm{V}$ priebehu prvého desatročia fungovania hodnoverného miesta v Banskej Bystrici jeho agenda obsahovala najviac svedectiev o právnych úkonoch, ktoré sa týkali zastupovania strany v právnom konaní, teda prokuračných listín (litterae procuratoriae), pričom za celé nami sledované obdobie sme právnych aktov tohto druhu identifikovali 72 . Druhým najpočetnejším typom dokumentov boli plnomocenstvá (l. plenipotentiales) v počte 41 .

Z dosvedčovacích listín, ktoré vydala Banskobystrická kapitula bola typovo najviac zastúpená protestačná listina (l. protestationes seu conradictoriae), ked’ za 10 rokov bolo v protokole zapísaných 41 takýchto dokumentov. Odvolacích listín (l. revocatoriae) bolo zapísaných 8 . V počte 23 boli zastúpené vyhlásenia - fasie, medzi ktoré zaradujeme svedectvá $\mathrm{s}$ trvalou platnostou (fassiones perennales), zmluvné vyhlásenia (fassiones contractuales) a odstupovacie listiny (l. cessionales). Zálohové, či dlžobné úpisy (l. pignoratoriae) boli vystavené len 2 a svedectiev (l. testimoniales) 5. Čo sa týka vyhotovovania jednoduchých odpisov listín - transsumptov, $\mathrm{v}$ protokole ich bolo nájdených 5 .

Posledná hojne zastúpená skupina záznamov v protokole súvisela s dohladávaním dokumentov v archíve hodnoverného miesta. Išlo o všeobecné vyšetrovacie listiny (requisitoria generalia), ktoré boli zasielané panovníkom, krajinským sudcom, sedmipanskou tabul'ou z dôvodu dohladania $\mathrm{v}$ archíve hodnoverného miesta, bud' konkrétneho dokumentu, prípadne všetkých dokladov

${ }_{14}$ Bližšie k typológii právnych aktov pozri: Láclavíková - Švecová 2007. 
týkajúcich sa určitej kauzy, ktoré mohli byt použité vo vyšetrovanom prípade. Takýchto záznamov bolo 31 .

Okrem spomenutých kategórií boli zaprotokolované napríklad aj cisárske nariadenia, úradné odpovede konventu na cisárske nariadenia a niekolko nezaradených dokumentov.

Najviac zaprotokolovaných dokladov bolo v roku 1782 a to 36; najmenej v roku 1789, 11 (v tomto prípade vynechávame rok 1780, kedžze hodnoverné miesto bolo prestahované do Banskej Bystrice a tu pôsobilo len od 1. augusta).

Listiny zapísané v protokole boli dominantne v latinskom jazyku. Mad’arčina a slovenčina sa vyskytujú sporadicky a nemčina okrem odpisov starších dokumentov vôbec (DABB, f. K-BB, k. P113), čo je zaujímavé vzhladom na presadzovanie nemčiny ako administratívneho jazyka Jozefom II., konkrétne intimátom Miestodržitel’skej rady vydaným 4. júna 1784 (Markov 1973, 117). I všeobecné vyšetrovacie listiny (requisitoria generalia), zasielané kapitule pod pečatou panovníka, prípadne krajinského sudcu, boli aj po roku 1784 písané v latinskom jazyku. ${ }^{15}$

Vydávanie všetkých dokumentov sa riadilo krajinským právom, a teda mali platnosṫ v celej krajine. Výnimkou boli plnomocenstvá, ked’ právomoc kapituly bola obmedzená len na susedné stolice (DABB, f. KVBD, 1754 - 1830,CV19C II., 45).

\section{Archív hodnoverného miesta v rokoch 1780 - 1790}

Otom, že bol archív na dobre chránenom mieste, svedčí fakt, že sa zachoval neporušený napriek niekolkým ničivým požiarom v meste. Napríklad v máji 1783 vypukol v Banskej Bystrici požiar, ktorý mal okrem mnohých ludských obetí aj devastačné materiálne následky. Zničil priestor s príbytkami kapituly, rozšíril sa na novopostavenú biskupskú rezidenciu, kde zároveň zhoreli diecézne protokoly. Zasiahol všetky mestské kostoly a 340 domov (Schematismus 1876, 50; Lacko 2011, 141). Naštastie archív hodnoverného miesta zostal uchránený. V protokole hodnoverného miesta je za rok 1783 zapísaných o viac ako polovicu menej právnych aktov(konkrétne 14), ako v predchádzajúcom roku (36), ale aj nasledujúcom (34), no zmienka o požiari je spomenutá len v súvislosti $\mathrm{s}$ jedným dokumentom, ktorý je $\mathrm{v}$ protokole kvôli poškodeniu prepísaný vo fragmente. Tento dokument sa mal práve v čase požiaru nachádzat’ u notára (DABB, f. K-BB, k. P113, 120).

Reformným snahám Jozefa II. sa nevyhli ani hodnoverné miesta, resp. ich archívy. Na zistenie stavu archívov hodnoverných miest sa zameral cisár Jozef II. od roku 1786. Podla cisárskeho mandátu číslo 2293 z 24. júna 1786 bolo Banskobystrickej kapitule prostredníctvom sedmipanskej tabule oznámené (totožná korešpondencia bola poslaná aj iným hodnoverným miestam), aby kapitula ako hodnoverné miesto, $\mathrm{v}$ prípade ak nemá dôsledne vypracované elenchi ${ }^{16} \mathrm{k}$ zaprotokolovaným dokumentom vydaným a uloženým $\mathrm{v}$ archíve hodnoverného miesta, dôsledne vypracovala takéto elenchi. Ďalej sa požadovalo zhotovit presný popis rozsahu archívu, spôsob jeho uchovávania a popis vykurovania miestností, v ktorých sa nachádzal. Registrácia mala byt' uskutočnená podla zaužívanej normy. K tejto činnosti sa malo pristúpit ihned, a pokial' nebola dokončená, boli hodnoverné miesta povinné každých 15 dní posielat správu panovníkovi, ako práce pokračujú (DABB, f. K-BB, k. P120, nečíslované; DABB, f. K-BB, k. P113, 249-250).

Banskobystrická kapitula poslala prvú a zároveň najobsiahlejšiu správu ohladom archívu 23. júla toho istého roku. V správe sa konštatovalo, že archív bol po prevzatí v roku 1780 vo velmi

15 V Diecéznom archíve sa nachádzajú spomínané dokumenty nielen ako odpisy v protokole, ale dokumenty od roku 1785 i ako originály (DABB, f. K-BB, k. P120).

16 Elench - ide o registratúrnu knihu, ktorej obsahom sú menné alebo vecné heslá, ktoré sú nápomocné pri orientácii v archivovaných dokumentoch, s ich presnou registráciou. 
neusporiadanom stave. Všetky spisy boli vzájomne domiešané. Z tohto dôvodu museli byt’ spisy usporiadané do fasciklov a označené číslami. Niektoré už boli v danom čase registrované, ale niektoré iba v procese registrácie. Protokolov bolo podla správy 30, z čoho 25 so svojimi elenchami, k zvyšným 5 protokolom boli elenchi práve v procese vyhotovovania.

D̃alšie informácie sa týkali pomerne podrobného opisu priestoru archívu hodnoverného miesta, kde sa uchovávali písomnosti a autentická pečat', pričom členovia kapituly ho vyhodnotili ako vel'mi bezpečný (DABB, f. K-BB, k. P120, nečíslované; DABB, f. K-BB, k. P113, 250-252). ${ }^{17}$

Ďalší mandát $\mathrm{z}$ dôvodu doplnenia informácií bol z Budína poslaný 1 . augusta 1886 . Predmetom záujmu bola tentokrát informácia, ktorá súvisela so schránkami, skriňami, kde boli dokumenty uchovávané. Ďalej bolo pripomenuté, že elenchi, ktoré existujú, majú byt’ hodnoverne prepísané a tieto kópie majú byt' ihned' poslané do Budína (DABB, f. K-BB, k. P120, nečíslované; DABB, f. K-BB, k. P113, 253-254).

Dňa 20. augusta sa v odpovedi dočítame, že žiadne skrine sa v archíve konventu nenachádzajú a dokumenty sú uložené a „koldokola“ uzavreté v schránkach ${ }^{18}$ (DABB, f. K-BB, k. P120, nečíslované ; DABB, f. K-BB, k. P113, 255-256).

Pôvodne mal byt proces registrácie ukončený do konca aktuálneho roku, teda roku 1886, no táto činnost’ sa neustále predlžovala. Kapitula bola pravidelne vyzývaná, aby svoju činnost’ urýchlila. Posledný dokument tohto charakteru v protokole kapituly nachádzame s datovaním 22 . októbra 1789 a je odpoved’ou na d’alšie cisárske nariadenie číslo 5601 zaslané toho istého roku 30. septembra. Kapitula v odpovedi uvádza, že výzva na urýchlené odovzdanie vypracovaných kópií elenchov je neopodstatnená, pretože túto povinnost' si kapitula už splnila (DABB, f. K-BB, k. P113; DABB, f. K-BB, k. P113, 306-307).

Všetky vyššie uvedené snahy o zistenie stavu jednotlivých archívov a množstva dokumentov v nich (okrem sprehladnenia, ktoré tieto archívy nevyhnutne potrebovali) sledovali svoj hlavný ciel' - centralizáciu archívov hodnoverných miest. Na jeseň 1789 totiž Jozef II. vydal jeden zo svojich mnohých mandátov, podla ktorého mali byt archívy hodnoverných miest sústredené do centrálneho depozitára v Budíne(Gregor 2017, 98; Javošová - Kuzmíková 2001, 266).

Plánovaný zámer sa však nakoniec neuskutočnil. Na jednej strane sa cisárske plány v danej sfére stretli s odmietnutím a proti reakciou dotknutých strán, na strane druhej jednoznačne najviac situáciu ovplyvnila celková politická klíma a začiatkom nasledujúceho roka smrt’ samotného cisára (Schematismus 1876, 48). ${ }^{19}$

17 Priestor, kde boli archívne spisy uchovávané bol opísaný ako kamenný a klenbový, rozlohou štvorcový. Viedla do neho brána, ktorá od smeru vchodu bola železná. Nachádzalo sa tu taktiež okno opatrené železnými okenicami. Spolu so spismi bola v tomto priestore uchovávaná aj pečat. Na daný priestor nadväzovala d’alšia prázdna miestnost', za ktorou bola pracovňa. $V$ pracovni boli spisy registrované do protokolov, ktoré tu boli uchovávané. Datované 23.júla 1786 (DABB, f. K-BB, k. P120, nečíslované).

18 Počet takýchto puzdier - schránok (v pôvodnom latinskom texte forulus, i, m.) bol 135, z ktorých bolo spismi naplnených 15 . Ostatné boli prázdne. Rozmer jednej schránky bol 2 stopy a celá zostava schránok mala spolu 2 siahy.

19 „Etiam archivum hoc conventuale 1789 Budam transferri iussum est. (prot. Dioec. 1790 p. 24); verum mandatum hoc capitulo moram ex mora nectente, effectui non est datum: sequunta non multo post et retractatione et morte mandantis" (Schematismus 1876, 48). 


\section{Záver}

Počas vzniku Banskobystrickej diecézy v roku 1776 bola pri biskupstve ustanovená kapitula so šiestimi kanonikmi, ktorá v roku 1780 začala po prenesení archívu Turčianskeho konventu vykonávat činnost’ hodnoverného miesta.

Uvedené zmeny vyplynuli z dlhodobej potreby rozdelenia Ostrihomskej arcidiecézy na menšie správne cirkevné jednotky, pričom tento proces urýchlilo rozpustenie Spoločnosti Ježišovej v roku 1773, čím sa uvolnili ako personálne, tak aj finančné a hospodárske zdroje, viazané na cirkev. Vzniknutú situáciu Mária Terézia využila v prospech dismembrácie Ostrihomskej arcidiecézy, ktorú na jej návrh odobril aj pápež. Panovníčka uskutočnila tento akt z pozície svojej moci, odvolávajúc sa na patronátne právo uhorských panovníkov a uplatňujúc politiku cisárskeho dvora, ktorej typickou črtou bolo zasahovanie do cirkevných záležitostí v duchu jozefinizmu. V rámci pokračujúcej reorganizácie štátnych i cirkevných inštitúcií bol po vzniku Banskobystrickej diecézy do Banskej Bystrice presunutý i archív hodnoverného miesta Turčianskeho konventu. Týmto aktom prevzala Banskobystrická kapitula funkciu hodnoverného miesta, ktorú vykonávala v nami sledovanom časovom horizonte pod pečatou Turčianskeho konventu. Z dokumentu, akým je protokol hodnoverného miesta z rokov 1780 - 1795, a z kanonických vizitácií z roku 1785, možno rekonštruovat fungovanie inštitúcie v prvom desatročí svojho pôsobenia v Banskej Bystrici. Poznáme personálne obsadenie kapituly, činnost’ a agendu hodnoverného miesta.

Reformy uskutočňované Jozefom II. neobišli ani hodnoverné miesta, ktoré boli v tomto čase už v záverečnom období svojho fungovania. Ak by nedošlo $\mathrm{k}$ smrti panovníka a k celkovej zmene politickej klímy v Európe v roku 1789, pravdepodobne by k zániku hodnoverných miest došlo skôr ako v roku 1874. O tejto skutočnosti svedčí smerovanie politiky Jozefa II. zjavné z nariadení, ktoré boli zamerané na registráciu dokumentov v archíve kapituly. Možno to hodnotit ako prípravu na zistenie stavu a obsahu jednotlivých archívov hodnoverných miest, ktoré mali byt následne centralizované v Budíne. Ešte v roku 1789 hrozilo, že sa archív hodnoverného miesta bude stahovat' opät', tentokrát do Budína. Mandát Jozefa II., ktorý to nariad’oval, však nenadobudol účinnost'. Dôvodom bolo jeho odvolanie a následne smrt’ panovníka. Banskobystrická kapitula tak nad’alej vykonávala činnost̉ hodnoverného miesta až do zániku tejto inštitúcie zákonným článkom XXXV/1874 o královských notároch, od roku 1802 už s vlastnou pečatou.

\section{REFERENCES}

\section{Primary sources}

Štátny archív v Banskej Bystrici (d’alej ŠABB), fond (d’alej f.). Zbierka matrík (1594 - 1952) (d’alej ZM) kniha Matricula defunctorum (d’alej MD) 1780 - 1841. Rímskokatolícka cirkev - Farnost’ Banská Bystrica (d’alej RC - FBB)

Diecézny archív Banská Bystrica (dalej DABB), fond (d’alej f.) Kapitula - Banská Bystrica (d’alej K-BB), kartón (d’alej k.), P113, Protocollum loci credibilis 1780 - 1795 (dalej PLC)

Diecézny archív Banská Bystrica (d’alej DABB), fond (d’alej f.) Kapitula - Banská Bystrica (d’alej K-BB), kartón (dalej k.), P115

Diecézny archív Banská Bystrica (d’alej DABB), fond (dalej f.) Kapitula Banská Bystrica (d’alej K-BB), kartón (d’alej k.), P120, Acta loci credibilis (1785 - 1795) protocollata (dalej ALCP)

Diecézny archív Banská Bystrica (d’alej DABB), fond (dalej f.) Kánonické vizitácie Banskobystrickej diecézy 1754 - 1830 (dalej KVBD), CV19C I. 
Diecézny archív Banská Bystrica (dalej DABB), fond (dalej f.) Kánonické vizitácie Banskobystrickej diecézy 1754 - 1830 (dalej KVBD), CV19C II.

\section{Secondary sources}

Brendza, Gabriel. 2003. História sídelnej Banskobystrickej kapituly. In Zubko, Peter, Hišem, Cyril (eds.). Kapituly kanonikov. Zborník príspevkov monotematického seminára s medzinárodnou účastou z cirkevných dejín, Košice 13. marca 2003. Košice, 107-116.

Gregor, Martin. 2017. Vývoj hodnoverných miest v Uhorsku. In Brtko, R. et al. Notárstvo a iné právnické profesie v historickom vývoji. Praha.

Javošova, Erika - Kuzmiková, Miriam. 2001. Verejnoprávna funkcia Spišskej kapituly v stredoveku. In Studia archaelogica Slovaca mediaevalia 3-4, 265-271.

Juhaniak, Marián. 2016. Dejiny banskobystrickej kapituly kanonikov. Diplomová práca. Univerzita Komenského v Bratislave. Badín.

Jurkovič, Emil. 2005. Dejiny královského mesta Banská Bystrica. Banská Bystrica.

Koniarová, Anna.2002. Dejiny Banskobystrickej diecézy v 18. a 19. storočí. Banská Bystrica.

Krapka, Emil - Mikula, Vojtech. 1990. Dejiny Spoločnosti Ježišovej na Slovensku. Cambridge, Ontario, Canada.

Lacko, Richard et al. 2011. Banskobystrické biskupstvo, Cestou Cirkvi je človek. Banská Bystrica.

Láclavíková, Miriam - Švecová, Adriána. 2007. Pramene práva na území Slovenska I. Trnava.

Markov, Jozef. 1973. Odraz politických zápasov v obecnej správe Banskej Bystrice v 16. - 19. storočí. Bratislava.

Mišík, Mikuláš. 1963. Všeobecné dejiny. In Štilla, Miloš (eds.). Zniev a okolie. Martin.

Schematismus. 1876. Schematismus historicus Dioecesis Neosoliensis pro anno saeculari MDCCCLXXVI. Neosolii.

Takács, Imre (ed.). 1992. A magyarországi káptalanok és konventek középkori pescétjei. Budapest.

Tomko, Jozef. 1995. Zriadenie Spišskej, Banskobystrickej a Rožňavskej diecézy a královské patronátne právo v Uhorsku. Spišská Kapitula - Spišské Podhradie.

Winter, Eduard. 1945. Josefinismus a jeho dějiny. Příspévky k duchovním dějinám Čech a Moravy 1740 - 1848. Praha.

Zubko, Peter. 2003. Vnútorné dejiny Košickej kapituly. In Zubko, Peter - Hišem, Cyril (eds.). Kapituly kanonikov. Zborník príspevkov monotematického seminára s medzinárodnou účastou z cirkevných dejín, Košice 13. marca 2003. Košice, 7-16.

Mgr. Zuzana Mičková, PhD.

Department of History of State and Law

Law Faculty Matej Bel University in Banská Bystrica

Komenského 20

97401 Banská Bystrica

Slovakia

zuzana.mickova@umb.sk

ORCID ID: 0000-0002-3481-3654 
doc. PhDr. Peter Mičko, PhD.

Department of History

Faculty of Arts

Matej Bel University in Banská Bystrica

Tajovského 40

97401 Banská Bystrica

Slovakia

peter.micko@umb.sk

ORCID ID: 0000-0002-0073-531X 